\title{
To Discuss the Construction of Dual-teachers in Higher Vocational Colleges-Take Wuhan Polytechnic as an Example
}

\author{
Wei WANG \\ Department of Computer, Wuhan Polytechnic, Wuhan 430074, China \\ 20151912@qq.com
}

Keywords: Dual-teachers; Construction of teachers; Management mechanism; Incentive mechanism.

\begin{abstract}
Higher vocational colleges cultivate highly skilled talents, the training of high-skilled talents requires dual-teachers. This article discusses how to establish a professional and part-time dual-teachers team in Wuhan Polytechnic. To establish and improve the management mechanism and incentive mechanism of dual-teachers is the institutional guarantee for the establishment of dual-teachers. This paper analyzes the current dual-teachers' management mechanism and incentive mechanism, and put forward some constructive suggestions. Our top priority is to build a professional and part-time teachers team. Establish and improve the current dual-teachers management mechanism and incentive mechanism.
\end{abstract}

\section{Introduction}

The ministry of education noted in a document entitled "the quality of education teaching in higher vocational education", document no. 16 of 2006, "the higher professional education should pay attention to the construction of dual-teachers. As early as 1998, the state education commission first made clear the concept of "dual-teachers" teacher in the view of "deepening the education teaching reform for the $2 \mathrm{l}$ century". Dual-teachers are teachers of higher vocational colleges must have certain theoretical knowledge as teachers. It is necessary to have certain practical ability of the engineer. However, the lack of dual-teachers is a prominent bottleneck to implement the policy of "vigorously developing professional education". The higher vocational colleges shoulder the mission of cultivating the dual-teachers. We should establish a system and method to train the dual-teachers. In this paper, we can use "delivery", "training", " exercise", "teaching"," bringing" and " hiring" the six words policy to train the dual-teachers.

\section{Delivery}

Delivery means selecting some teachers to pursue further education. We take Wuhan Polytechnic as an example. This college has developed a master's degree project, the school's teachers were sent to Wuhan University or Huazhong University of Science and Technology for a master's degree. Teachers with lower education levels are encouraged to continue their studies at key universities. Teachers only have a master's degree to evaluate intermediate titles. In addition, the school invests a large amount of funds each year to send young teachers to Germany, Singapore, Australia, the United States, Canada, Finland and other countries to train. Learn the advanced education ideas and teaching methods of these countries, and then promote and promote them through reports and lectures. The way to send teachers to key universities and foreign countries is mainly aimed at teachers who are less theoretical and have more hands-on skills. This way of sending out learning is one of the ways to train dual-teachers.

\section{Training}

Training refers to the train of teachers through multiple channels. 


\section{To Train Dual-Teachers Faculty through Various Types of Teaching Competitions.}

By developing multimedia courseware, speaking competition, professional competition, teaching competition, etc. In order to make young teachers grow up rapidly, Wuhan Polytechnic holds a variety of teaching competitions every year. The teachers, by taking part in the competition, quickly grew up in their respective teaching positions through the guidance of excellent players. More and more young teachers are becoming the backbone teachers and professional leaders. In order to consolidate the achievements of state-level demonstration construction, the school has conducted courses, lectures and other competitions, and then selected the director and professional leader of the teaching and research office. Through these diverse and all-round teaching competitions, teachers have a deeper change in the understanding of the curriculum and the understanding of the professional, and the professional level and teaching theory have been improved. They have grown up to be dual-teachers who can "train highly skilled talents".

\section{Curriculum Reform and Professional reform To Train Excellent Dual-Teacher Team}

Curriculum reform and professional reform have stimulated the enthusiasm and creativity of teachers and enriched the theoretical knowledge of teachers. The vocational colleges are different from the universities. Through curriculum reform and professional reform, the new curriculum concept and students' concept are forming. It also changes the traditional teaching mode and teaching method. This new teaching mode and teaching method can cultivate "highly skilled talents". Take Wuhan Polytechnic as an example, the school organizes curriculum reform and the declaration of professional reform subject each year. In order to improve the level and ability of teachers in curriculum reform and professional reform, Hongqu LI, the president, teaches the curriculum reform and professional reform of young teachers personally. This kind of curriculum reform and professional reform is very helpful for teachers to improve their professional level and practical ability, which is one of the important ways to train teachers of dual-teachers.

\section{The Production and Learning Research Combine to Train the Team of Dual-Teachers}

The combination of industrial and university-industry research and research includes: enterprise cooperation curriculum, university-enterprise cooperation project, research and development technology, etc. The school should attach importance to the prominent role of scientific research in the cultivation of dual-teachers. Schools should encourage teachers to undertake research projects and teaching reform projects in combination with professional curriculum reform. Teachers should be responsible for the application research projects related to the major, especially the horizontal application of the integration of enterprises and enterprises. In the process of participating in the enterprise curriculum, enterprise project and technology development, the teacher has mastered the technological development status and development trend of the industry and enterprises while improving the professional level. The combination of production, teaching and scientific research is also one of the important ways to train teachers.

\section{Exercise}

Exercise is the teacher's grass-roots exercise. Special course teachers must be arranged to conduct professional practice training on the front line of enterprises and enterprises, especially the new teachers who lack professional experience. Use summer vacation to send teachers to the enterprise. Participate in the first line production and management of enterprises. In the process of exercising, teachers' hands-on ability has been improved. Wuhan Polytechnic sends teachers to the first line practice of Foxconn, Microsoft and Huawei every year. The computer department of Wuhan Polytechnic stipulates that new teachers must work in the machine room for a year before teaching. In addition, a certain number of teachers also serve as counselors. It is an important way to cultivate the teacher's ability to practice and cultivate the teacher. It is also an important way to train teachers of dual-teachers. 


\section{Teaching}

Teaching means old education new, strong education weak. In order to ensure that young teachers can better perform the duties of teachers. Wuhan Polytechnic will conduct pre-job training for new teachers after 2006. The main way is master education apprentice. Organize young teachers to conduct teaching exercises and organize new teachers to listen to the teaching of experienced teachers. The experienced teacher is responsible for the teaching task of demonstration class. The cultivation methods of these dual-teachers are mainly aimed at the new teachers. New teachers often have strong theoretical knowledge, lack of practical ability and classroom teaching experience. With the help of the professional leader, the backbone teachers help, these new teacher soon grow up to be have a certain theoretical knowledge, and have a certain practical ability of dual-teachers, they are soon to be able to do "high-skilled talents" training.

\section{Bringing}

Introduce technical backbone and subject lead. Wuhan Polytechnic has introduced the dean of the department of computer and the dean of the department of architecture. Wuhan Polytechnic also introduced a large number of highly skilled personnel from the enterprises, and they were the force of the dual-teachers team. Most of these people are professors at key universities and senior engineers in enterprises. Some of them have strong theoretical skills, while others have strong professional skills. They are the nurturing of the dual-teachers faculty. The bringing is mainly aimed at the shortage of high-end technical talent in schools. These imported high-end talents quickly went to the forefront of the national and Hubei province professional education.

\section{Hiring}

In contrast to the five methods mentioned above, hiring refers to the hiring of a technical backbone to serve as part-time teachers. But the first five ways to train are full-time teachers. In order to implement the decision of the state council on vigorously developing professional education, according to the ministry of education's opinions on comprehensively improving the teaching quality of education of higher vocational colleges. We should strengthen the construction of dual-teachers and dual-teachers quality teachers in higher vocational colleges and train highly skilled professionals. The education department of Hubei province has established the teaching post of "Chutian skills master" in the provincial higher vocational colleges. Wuhan Polytechnic began to hire "Chutian skills master" since from 2008. The main responsibilities of the "Chutian skills master" are: complete and systematic teaching of a professional practical skills course, and guide the actual training of the students. They teach students the professional skills required for this professional production practice. They participate in the construction of dual-teachers structure and dual-teachers quality teaching team. They participate in the research and practice of professional teaching reform. They offer advice and advice on the training of professional talents. The hiring of the "Chutian skills master" is not only in line with the demand of "cultivating high-skilled talents", but also directly trains a large number of dual-teachers. The hired "Chutian skills master" is a part-time teacher, but has a variety of functions. The hiring of "Chutian skills master" is an important supplement to the dual-teachers in higher vocational colleges, which is the source of sustainable development of higher vocational colleges. It is a long - term process to set up a professional and part-time vocational college dual-teachers team. It is necessary to be a full-time teacher and a part-time teacher.

\section{Summary}

The construction of dual-teacher teaching staff in higher vocational colleges is a systematic project. It not only requires the efforts of higher vocational colleges, but also the wide participation of government, enterprises and society. It should be consistent throughout the teacher's career to train the 
dual-teacher in higher vocational colleges. Only in this way can we build a team of dual-teacher with sufficient quantity and high level. Only in this way can we "vigorously develop vocational education", the higher vocational education spring will come true.

\section{References}

[1] GAO Guilin, The design and implementation of teacher training programs in higher vocational colleges. Master's thesis of Central China Normal University.2007.5.

[2] XU Shibin, A probe into teacher management strategy of business vocational colleges, Nanchang: Vocational \& Technical Education Forum.2010.6.

[3] WANG Qianxin, Research on the development strategy of higher vocational technical colleges[M].Wuhan: Huazhong University of Science and Technology press.2005.

[4] The ministry of education. Some opinions on improving the teaching quality of education in higher vocational education.2006.

[5] HU Huoqing. The practice of teaching staff in jiujiang vocational college. Nanchang: Vocational \& Technical Education Forum.2010.7.

[6] HONG Fuxing. On the innovation of teacher evaluation system in higher vocational colleges. Journal of Hunan University of Science and Engineering.2005.8. 